\title{
The microbiologic spectrum of dacryocystitis
}

\author{
Ban Luo ${ }^{1}, \mathrm{Mu} \mathrm{Li}^{1,2}$, Nan Xiang ${ }^{1}$, Weikun Hu${ }^{1}$, Rong Liu ${ }^{1}$ and Xiaoqin Yan ${ }^{1 *}$
}

\begin{abstract}
Background: To investigate the microbiologic spectrum of dacryocystitis in adult and pediatric groups, specifically the microbiologic differences between chronic dacryocystitis with nasolacrimal duct obstruction (NLDO) and acute dacryocystitis in pediatric group.

Methods: This retrospective study was reviewed for demographic and microbiologic profile of dacryocystitis. The culture results were reported.

Results: Sixty-four adults and one hundred and five pediatrics with dacryocystitis were included in this study. Of all adults, only chronic dacryocystitis with NLDO was observed. Of all pediatric patients, 89 had chronic dacryocystitis with NLDO and 16 had acute dacryocystitis. Gram positive and negative isolates were numerically equal in adult group (both 36(48.65\%)), while gram positive isolates were the major organism in pediatric group (71(58.68\%)). Streptococcus pneumonia was the most common isolate in both adult $(11(14.86 \%))$ and pediatric (30(24.79\%)) dacryocystitis. For both pediatric subgroups, gram positive isolates were the major organism (59(57.84\%) for chronic dacryocystitis with NLDO and 12 (63.16\%) for acute dacryocystitis). However, the leading isolates in those two subgroups were distinct, with Streptococcus pneumonia (29(28.43\%)) being most common in chronic dacryocystitis with NLDO and Staphylococcus aureus $(8(42.11 \%))$ being most common in acute dacryocystitis.

Conclusions: In adult group, gram negative isolates were more common in dacryocystitis than before. In pediatric group, gram positive isolates were still the major infection pathogen. Moreover, the more virulent organisms were more common in acute dacryocystitis than chronic dacryocystitis with NLDO.
\end{abstract}

Keywords: Microbiologic spectrum, Dacryocystitis, Adult and pediatrics, Acute and chronic

\section{Background}

Dacryocystitis is the most common disease of lacrimal drainage system. The reason for this infection is blockage of the lacrimal drainage system, which could further lead to the accumulation of tears and creation of a fertile environment for secondary bacterial infection, and dacryolith formation [1-3]. Bacterial dacryocystitis makes up about $60.8-94.9 \%$ of all dacryocystitis $[4,5]$. Especially children with immature immune system could be more predispose to a severe infection [6]. The

\footnotetext{
*Correspondence: yanxiaoginyy@126.com

'Department of Ophthalmology, Tongji Hospital, Tongji Medical College, Huazhong University of Science and Technology, 430030 Wuhan, China

Full list of author information is available at the end of the article
}

microorganisms reproduce in the lacrimal passage and result in the relevant symptoms, like epiphora, pyorrhea, ophthalmodynia and conjunctival hyperaemia, etc. Those symptoms would bring great discomfort to the patients and reduce their life quality. When not treated appropriately and timely, the infection might expand and lead to permanent injury of the lacrimal passage, orbital cellulitis, abscess, meningitis, cavernous sinus thrombosis, and even life-threatening situations [7-10]. In addition, the causes and the infection pathogen might also be distinct for chronic and acute dacryocystitis [11-14]. Thus, the understanding of microbiologic spectrum and control of microbiologic infection is critical and important in the treatment of dacryocystitis. However, there are

C C The Author(s). 2021 Open Access This article is licensed under a Creative Commons Attribution 4.0 International License, which permits use, sharing, adaptation, distribution and reproduction in any medium or format, as long as you give appropriate credit to the original author(s) and the source, provide a link to the Creative Commons licence, and indicate if changes were made. The images or other third party material in this article are included in the article's Creative Commons licence, unless indicated otherwise in a credit line to the material. If material is not included in the article's Creative Commons licence and your intended use is not permitted by statutory regulation or exceeds the permitted use, you will need to obtain permission directly from the copyright holder. To view a copy of this licence, visit http://creativecommons.org/licenses/by/4.0/ The Creative Commons Public Domain Dedication waiver (http://creativecommons.org/publicdomain/zero/1.0/) applies to the data made available in this article, unless otherwise stated in a credit line to the data. 
relatively few studies focusing on the microbiologic characteristics of dacryocystitis and comparing the microbiologic difference between chronic and acute dacryocystitis [15].

Previous studies have reported that the pathogens in dacryocystitis were similar to those found in the upper respiratory passage and on the skin $[2,16]$. However, the application of broad-spectrum antibiotics might have an influence on the microbiologic spectrum of dacryocystitis [17]. Although gram positive bacterium was reported to be predominant in most studies, some rarer gram negative bacteria and methicillin-resistant Staphylococcus aureus became more common in dacryocystitis recently $[14,15,17,18]$. Patients with dacryocystitis often received empiric antibiotic treatment without or before the culture results, which need time to acquire [16]. Thus, changes in the microbiologic spectrum might obviously affect the therapeutic effect and outcome of dacryocystitis.

Accordingly, we performed this retrospective study to investigate the microbiologic spectrum of dacryocystitis in central China to provide microbiologic data for the clinical treatment of dacryocystitis.

\section{Methods}

\section{Subjects}

In this retrospective study, we included patients with dacryocystitis in the department of ophthalmology, Tongji hospital, Wuhan, China, from 2016.7 to 2017.7. This study was approved by the ethics committee of Tongji Hospital and performed in accordance with the tenets of the Declaration of Helsinki. Written informed consents were obtained from all participants. Patients were diagnosed as acute or chronic dacryocystitis based on their history, signs and symptoms. Chronic dacryocystitis was diagnosed as persistent epiphora and regurgitation of mucoid or mucopurulent material on pressure over the sac area or during irrigation of the lacrimal drainage system. Besides that, when the lacrimal sac area showed manifestation of pain, redness, and swelling, it would be diagnosed as acute dacryocystitis. Nasolacrimal duct obstruction (NLDO) was diagnosed according to the lacrimal passage irrigation test results. All cases of epiphora caused by lacrimal disease other than NLDO, patients with any history of maxillofacial surgery, maxillofacial trauma or maxillofacial tumor and patients who had received any topical or systemic antibiotics in the past one week ahead of their microbiologic culture were excluded [14].

\section{Sample collection and microbiologic culture}

To collect the samples, a lacrimal probe would be placed to the lacrimal sac through the lower lacrimal ductile. Then the probe core within the probe would be removed. After that, a sterile syringe would be attached to the hollow lacrimal probe, to aspirate the lacrimal sac secretion. Once the samples were collected, they were sown immediately in transport medium. Transport medium were delivered to the laboratory within $15 \mathrm{mi}$ nutes at room temperature. Samples from transport medium were planted in sheep blood agar, eosin methylene blue, USP althernative, Sabouraud's dextrose agar and chocolate agar. Reproduction was checked intermittently. Clinically significant growths in samples taken from flora regions were reported. Strains were identified by manual biochemical reaction methods and/or instruments (VITEK-2-COMPACT system, bioMérieux, France and matrix-associated laser desorption ionization time-offlight mass spectrometry, MALDI-TOF MS, Germany).

\section{Data analysis}

The Chi-square test (SPSS software 19.0, IBM Corp., Armonk, NY, USA) was used for comparing ratio differences between groups. Statistical significance was defined as a $p$ value of $<0.05$.

\section{Results \\ Subject characteristics}

A total of 169 patients with dacryocystitis were included in this retrospective study. Of those patients, adult patients were 64 (37.87\%) and pediatric patients were 105 (62.13\%). In adult group, only chronic dacryocystitis with NLDO (64 (37.87\%)) was observed. In pediatric group, both chronic dacryocystitis with NLDO and acute dacryocystitis were observed. Among them, 89 (52.66\%) were patients with chronic dacryocystitis with NLDO, and 16 (9.47\%) were patients with acute dacryocystitis. There were $80(47.34 \%)$ male and $89(52.66 \%)$ female patients. The age range was from 0 to 80 years old, with the mean age of 16.6 years old. Among the 169 patients, 21 (12.43\%) of them had polymicrobial infections (Table 1).

\section{The microbiologic spectrum of dacryocystitis in adult and pediatric groups}

As summarized in Table 2, the total amount of adult samples was 74 . Among them, gram positive and negative isolates were numerically equal (both were 36 $(48.65 \%))$, gram positive isolate were not predominant in adult group. The leading gram positive isolates in adult were Streptococcus pneumoniae $(11(14.86 \%))$ and Coagulase Negative Staphylococci (9 (12.16\%)). For gram negative isolates in adult, Haemophilus influenza was relatively more frequent $(5(6.76 \%))$.

In pediatric group, the sample size was 121 , which was much bigger than that of adult group (74 samples). Among them, more than half of the samples (71 $(58.68 \%))$ were tested to be gram positive isolates, which 
Table 1 Study subject characteristics

\begin{tabular}{lllll}
\hline Characteristics & & Adult (\%) & Pediatric (\%) & Overall (\%) \\
\hline Number of patients & Chronic dacryocystitis with NLDO & $64(37.87 \%)$ & $89(52.66 \%)$ & $16(9.47 \%)$ \\
& Acute dacryocystitis & 0 & $62(36.69 \%)$ & $16(9.47 \%)$ \\
Number of patients & Male & $18(10.65 \%)$ & $43(25.44 \%)$ & $89(47.34 \%)$ \\
& Female & $46(27.22 \%)$ & $0-17$ & $0-80$ \\
Age range (years) & & $18-80$ & 0.6 & 16.6 \\
Mean age (years) & 42.7 & $12(7.10 \%)$ & $21(12.43 \%)$ \\
Number of patients with polymicrobial infections & $9(5.33 \%)$ & &
\end{tabular}

NLDO nasolacrimal duct obstruction

was equal to the proportion of gram positive isolates in adult group $(48.65 \%, p=0.172)$. The most common gram positive isolate in pediatric group was Streptococcus pneumoniae (30 (24.79\%)), followed by Staphylococcus aureus (14 (11.57\%)). Besides the gram positive isolates, the rest $32(26.45 \%)$ and $18(14.88 \%)$ samples were proven to be gram negative isolates and fungus isolates, respectively. The relatively more common gram negative isolate was Haemophilus influenza (7 (5.78\%)). Compared with adult group, the gram negative isolates were significantly less common (36 (48.65\%) vs. 32 $(26.45 \%), p=0.002)$ and the fungus samples were significantly more common $(2(2.70 \%)$ vs. 18 (14.88\%), $p=$ $0.007)$ in pediatric group.
The microbiologic spectrum of dacryocystitis in pediatric subgroups

As shown in Table 3, in both pediatric subgroups, gram positive isolates accounted for more than half of the total amount of microorganisms. 59 (57.84\%) isolates in chronic dacryocystitis with NLDO group and 12 (63.16\%) isolates in acute dacryocystitis group were gram positive isolates, with no significant proportion difference between two subgroups $(p=0.666)$. Besides that, the gram negative isolates were also equal in proportion in both subgroups (26 (25.49\%) vs. 6 (31.58\%), $p=0.581)$.

For chronic dacryocystitis with NLDO group, the leading gram positive isolate was Streptococcus pneumoniae

Table 2 The microbiologic spectrum of dacryocystitis in adult and pediatric groups

\begin{tabular}{|c|c|c|c|c|}
\hline & & Adults (\%) & Pediatrics (\%) & Total (\%) \\
\hline \multirow[t]{8}{*}{ Gram positive isolates } & Streptococcus pneumoniae & $11(14.86 \%)$ & $30(24.79 \%)$ & $41(21.03 \%)$ \\
\hline & Staphylococcus aureus & $6(8.10 \%)$ & $14(11.57 \%)$ & $20(10.26 \%)$ \\
\hline & Staphylococcus epidermidis & $2(2.70 \%)$ & $2(1.65 \%)$ & $4(2.05 \%)$ \\
\hline & Coagulase negative Staphylococci & $9(12.16 \%)$ & $3(2.47 \%)$ & $12(6.15 \%)$ \\
\hline & Streptococcus oralis & 0 & $8(6.61 \%)$ & $8(4.10 \%)$ \\
\hline & Viridans Streptococci & $5(6.76 \%)$ & $4(3.31 \%)$ & $9(4.62 \%)$ \\
\hline & Other gram positive isolates & $3(4.05 \%)$ & $10(8.26 \%)$ & $13(6.67 \%)$ \\
\hline & Gram positive isolates in total & $36(48.65 \%)$ & $71(58.68 \%)$ & $107(54.87 \%)$ \\
\hline \multirow[t]{7}{*}{ Gram negative isolates } & Pseudomonas aeruginosa & $3(4.05 \%)$ & $4(3.31 \%)$ & 7 (3.59\%) \\
\hline & Escherichia Coli & $3(4.05 \%)$ & $2(1.65 \%)$ & $5(2.56 \%)$ \\
\hline & Moraxella catarrhalis & $4(5.41 \%)$ & $3(2.47 \%)$ & $7(3.59 \%)$ \\
\hline & Haemophilus influenzae & $5(6.76 \%)$ & $7(5.78 \%)$ & $12(6.15 \%)$ \\
\hline & Haemophilus parainfluenzae & 0 & $2(1.65 \%)$ & $2(1.03 \%)$ \\
\hline & Other gram negative isolates & $21(28.38 \%)$ & $14(11.57 \%)$ & $35(17.95 \%)$ \\
\hline & Gram negative isolates in total & $36(48.65 \%)$ & $32(26.45 \%)$ & $68(34.87 \%)$ \\
\hline \multirow{5}{*}{$\begin{array}{l}\text { Fungus } \\
\text { isolates }\end{array}$} & Streptococcus mitis & 0 & $9(7.43 \%)$ & $9(4.61 \%)$ \\
\hline & Candida Parapsilosis & $1(1.35 \%)$ & 7 (5.79\%) & $8(4.10 \%)$ \\
\hline & Other fungus & $1(1.35 \%)$ & $2(1.65 \%)$ & $3(1.54 \%)$ \\
\hline & Fungus in total & $2(2.70 \%)$ & $18(14.88 \%)$ & $20(10.26 \%)$ \\
\hline & microorganisms in total & 74 (100\%) & $121(100 \%)$ & $195(100 \%)$ \\
\hline
\end{tabular}


Table 3 The microbiologic spectrum of dacryocystitis in pediatric subgroups

\begin{tabular}{|c|c|c|c|}
\hline Pediatric group & & Chronic dacryocystitis with NLDO (\%) & Acute dacryocystitis (\%) \\
\hline \multirow[t]{8}{*}{ Gram positive isolates } & Streptococcus pneumoniae & $29(28.43 \%)$ & $1(5.26 \%)$ \\
\hline & Staphylococcus aureus & $6(5.88 \%)$ & $8(42.11 \%)$ \\
\hline & Staphylococcus epidermidis & $2(1.96 \%)$ & 0 \\
\hline & Coagulase negative Staphylococci & $1(0.98 \%)$ & $2(10.53 \%)$ \\
\hline & Streptococcus oralis & $8(7.88 \%)$ & 0 \\
\hline & Viridans Streptococci & $3(2.94 \%)$ & $1(5.26 \%)$ \\
\hline & Other gram positive isolates & $10(9.80 \%)$ & 0 \\
\hline & Gram positive isolates in total & $59(57.84 \%)$ & $12(63.16 \%)$ \\
\hline \multirow[t]{7}{*}{ Gram negative isolates } & Pseudomonas aeruginosa & $3(2.94 \%)$ & $1(5.26 \%)$ \\
\hline & Escherichia Coli & $2(1.96 \%)$ & 0 \\
\hline & Moraxella catarrhalis & $3(2.94 \%)$ & 0 \\
\hline & Haemophilus influenzae & $6(5.88 \%)$ & $1(5.26 \%)$ \\
\hline & Haemophilus parainfluenzae & $2(1.96 \%)$ & 0 \\
\hline & Other gram negative isolates & $10(9.80 \%)$ & $4(21.05 \%)$ \\
\hline & Gram negative isolates in total & $26(25.49 \%)$ & $6(31.58 \%)$ \\
\hline \multirow{5}{*}{$\begin{array}{l}\text { Fungus } \\
\text { isolates }\end{array}$} & Streptococcus mitis & $9(8.82 \%)$ & 0 \\
\hline & Candida Parapsilosis & $7(6.86 \%)$ & 0 \\
\hline & Other fungus & $1(0.98 \%)$ & $1(5.26 \%)$ \\
\hline & Fungus in total & $17(16.67 \%)$ & $1(5.26 \%)$ \\
\hline & microorganisms in total & $102(100 \%)$ & $19(100 \%)$ \\
\hline
\end{tabular}

NLDO nasolacrimal duct obstruction

(29 (28.43\%)). However, for acute dacryocystitis group, the leading gram positive isolate was not Streptococcus pneumoniae but Staphylococcus aureus (8 (42.11\%)).

The microbiologic spectrum of dacryocystitis in male and female groups

In the male group, nearly half of the collected samples were gram positive isolates (47 $(48.96 \%)$ ), with the leading isolate to be Streptococcus pneumoniae (16 $(16.67 \%))$. The rest samples were gram negative isolates (36 $(37.50 \%))$ and fungus $(13(13.54 \%))$. In the female group, the results were similar to the male group. Among the total 99 samples, gram positive isolates occupied 60 samples $(60.60 \%)$, which is equal to the proportion of that in male group $(p=0.102)$. The leading gram positive isolate was still Streptococcus pneumoniae (25 (25.25\%)), followed by Staphylococcus aureus (14 (14.14\%)). Moreover, the gram negative isolates were 32 (32.32\%) and fungus samples were 7 (7.07\%), and the proportions of gram negative isolates and fungus in both male and female groups were not significantly different $(p=0.448$ and 0.136$)$ (Table 4).

\section{Discussion}

Dacryocystitis is mostly occurred with bacterial infections $[4,5]$, and might damage the normal structure of lacrimal duct [19]. In this retrospective study, we investigated the microbiologic culture results of dacryocystitis in adult and pediatric groups.

Similar to the endodontic infections, one microbiologic species could be nutrients for another one by the infections of lacrimal passage [16]. The polymicrobial infection rate of this study was $12.43 \%$ (21/169), which was equal to that of previous studies (7\%-30\%) [20,21]. The average number of microorganisms was 1.15 per culture, which was lower than that of previous studies, with an average of 1.5-2.3 microorganisms per culture $[14,16,22-24]$. The reason for this difference might be that the majority (17/21) of polymicrobial infection cases of our study were with only two microorganisms.

The female-to-male ratio of this study was 1.11 , which is significantly lower than the previous results [14-16]. The reason for this difference might be that the major $(105 / 169)$ included subjects of this study were pediatrics, with overall mean age of 16.6 years old, while the previous studies included more adult than pediatrics in their studies, with mean age of from 44 to 60 years old [1416]. Apart from pediatric group, the female-to-male ratio in adult group could increase to 2.56 in this study, which was consistent with the reported values of previous studies [14-16]. Contrary to the adult group, the female-tomale ratio in pediatric group was only 0.69 , indicating that there were less female patients than male patients 
Table 4 The microbiologic spectrum of dacryocystitis in male and female groups

\begin{tabular}{|c|c|c|c|c|}
\hline & & Male (\%) & Female (\%) & Total (\%) \\
\hline \multirow[t]{8}{*}{ Gram positive isolates } & Streptococcus pneumoniae & $16(16.67 \%)$ & 25 (25.25\%) & $41(21.03 \%)$ \\
\hline & Staphylococcus aureus & $6(6.25 \%)$ & $14(14.14 \%)$ & $20(10.26 \%)$ \\
\hline & Staphylococcus epidermidis & $3(3.13 \%)$ & $1(1.01 \%)$ & $4(2.05 \%)$ \\
\hline & Coagulase negative Staphylococci & $4(4.17 \%)$ & $8(8.08 \%)$ & $12(6.15 \%)$ \\
\hline & Streptococcus oralis & $6(6.25 \%)$ & $2(2.02 \%)$ & $8(4.10 \%)$ \\
\hline & Viridans Streptococci & $1(1.04 \%)$ & $8(8.08 \%)$ & $9(4.62 \%)$ \\
\hline & Other gram positive isolates & $11(11.45 \%)$ & $2(2.02 \%)$ & $13(6.67 \%)$ \\
\hline & Gram positive isolates in total & $47(48.96 \%)$ & $60(60.60 \%)$ & $107(54.87 \%)$ \\
\hline \multirow[t]{7}{*}{ Gram negative isolates } & Pseudomonas aeruginosa & $3(3.13 \%)$ & $4(4.04 \%)$ & $7(3.59 \%)$ \\
\hline & Escherichia Coli & $2(2.08 \%)$ & $3(3.03 \%)$ & $5(2.56 \%)$ \\
\hline & Moraxella catarrhalis & $4(4.17 \%)$ & $3(3.03 \%)$ & 7 (3.59\%) \\
\hline & Haemophilus influenzae & $8(8.33 \%)$ & $4(4.04 \%)$ & $12(6.15 \%)$ \\
\hline & Haemophilus parainfluenzae & $2(2.08 \%)$ & 0 & $2(1.03 \%)$ \\
\hline & Other gram negative isolates & $17(17.70 \%)$ & $18(18.18 \%)$ & 35 (17.95\%) \\
\hline & Gram negative isolates in total & $36(37.50 \%)$ & $32(32.32 \%)$ & 68 (34.87\%) \\
\hline \multirow{5}{*}{$\begin{array}{l}\text { Fungus } \\
\text { isolates }\end{array}$} & Streptococcus mitis & $7(7.29 \%)$ & $2(2.02 \%)$ & $9(4.61 \%)$ \\
\hline & Candida Parapsilosis & $5(5.21 \%)$ & $3(3.03 \%)$ & $8(4.10 \%)$ \\
\hline & Other fungus & $1(1.04 \%)$ & $2(2.02 \%)$ & $3(1.54 \%)$ \\
\hline & Fungus in total & $13(13.54 \%)$ & $7(7.07 \%)$ & $20(10.26 \%)$ \\
\hline & microorganisms in total & $96(100 \%)$ & 99 (100\%) & $195(100 \%)$ \\
\hline
\end{tabular}

in pediatric group. Previously, very few studies have investigated the sex ratio of dacryocystitis patients in pediatric group with relatively big sample size. Our current results indicated that the sex ratio of dacryocystitis patients in pediatric and adult groups might be different. Unlike in adult group, female patients might not be predominant in the pediatric group.

In the adult group, no acute dacryocystitis were observed, while in the pediatric group, both acute dacryocystitis and chronic dacryocystitis with NLDO were found. Previous studies have also reported that younger patients were more susceptible to acute dacryocystitis than chronic dacryocystitis with NLDO $[14,25]$. The immature immune system of children might be one reason for this phenomenon [6].

The predominant microbiologic spectrum (46-90\%) of dacryocystitis were reported to be gram positive isolates, while gram negative isolates only constitute $2.5-40 \%$ of pathogens [13-16, 26-28]. Contrary to those previous studies, our adult group study results showed that the gram positive isolates were not predominant, and gram positive and negative isolates were numerically equal in adult group (both $36(48.65 \%)$ ), indicating that gram negative isolates became more common and took more proportion in infection pathogen of dacryocystitis than before in adult group. However, in pediatric group, the results were still similar to the previous studies [13-16,
26-28], with gram positive isolates being the major organism $(71(58.68 \%))$ and gram negative isolates only taking a small proportion (32 (26.45\%)).

In adult group, the leading isolates were Streptococcus pneumoniae (14.86\%) and Coagulase negative staphylococci (12.16\%). In pediatric group, the leading isolates were Streptococcus pneumoniae (24.79\%) and Staphylococcus aureus (11.57\%). Thus, we could find that, in both adult and pediatric groups, Streptococcus Pneumoniae took the leading position, followed by Staphylococcus spp.. Those findings were similar to previous reports $[17,29,30]$, implying that Streptococcus pneumoniae and Staphylococcus spp. were the most common isolates in dacryocystitis. Because Streptococcus pneumonia was a normal inhabitant of nasopharynx, immunization might be necessary for the restriction of its spreads to other sites (e.g., the ocular tissue and organ) [31]. For gram negative isolates, the most frequent isolate was Haemophilus influenza in both adult $(5(6.76 \%))$ and pediatric (7(5.78\%)) groups, which was also consistent with previous reports [32, 33]. Besides that, compared with adult group, the fungus isolates were significantly more common in pediatric group (2 (2.70\%) vs. 18 (14.88\%), $p=0.007)$, implying that we should pay more attention to the anti-fungus treatment in pediatric dacryocystitis. 
We divided the pediatric group into chronic dacryocystitis with NLDO and acute dacryocystitis groups, and found that the proportions of both gram positive and negative isolates were not significantly different between chronic and acute infection groups. However, the leading isolates in those two groups were distinct. For pediatric chronic dacryocystitis with NLDO, the leading isolates was Streptococcus pneumonia (28.43\%), and for pediatric acute dacryocystitis, the leading isolates was Staphylococcus aureus (42.11\%). Previous study has also suggested that the bacterial spectrum of acute and chronic dacryocystitis was different. The more virulent isolates (e.g., Staphylococcus aureus) might be more common by acute dacryocystitis [13, 14]. Previous study has reported that Staphylococcus aureus is the leading isolates of acute lacrimal infection in pediatric group [34], which was consistent with our results. We speculated that besides the immature immune system, the shorter and narrower nasolacrimal duct and the immature Hasner valve could also contribute to the more susceptibility to the more virulent pathogen in pediatric group. The more virulent pathogen could progress more rapidly and be more harmful to the tissue, leading to the acute dacryocystitis. Thus, the children are more prone to the acute dacryocystitis. However, we should also notice that this investigation was a single-center study conducted in the central China. Thus, the study results could have geographical and racial bias.

In term of sex, the isolates distribution showed no significant difference between male and female groups, with the leading isolate still to be Streptococcus pneumonia. Sex might have less influence on the microbiologic spectrum of dacryocystitis.

In this study, we used the lacrimal probe with sterile syringe at the end to collect samples from lacrimal sac. Using this noninvasive method, we could directly reach the lacrimal sac and take samples from lacrimal sac to the sterile syringe for culture. Thus, the collected samples would not expose to the conjunctival sac, avoiding the potential contamination by normal flora. Major normal flora of conjunctival sac has been confirmed to be gram positive isolates $[2,17,35,36]$. Among them, Staphylococcus epidermidis accounts for about 57-87\% of isolates, while Streptococcus spp. only occupied 6\% [2, 17, 35, 36]. Meanwhile, our study showed that Streptococcus pneumoniae and Staphylococcus aureus were the most common isolates of dacryocystitis, which was different from the normal flora of conjunctival sac. Accordingly, we assume that the cultures obtained in this study was reliable, as there was a low possibility of contamination from conjunctival sac.

This study has certain limitations: First, this study was conducted in the central China, thus, our results might not be extrapolated to other geographical regions and races. Second, the incubation of microorganism relays on various conditions such as temperature, concentrations of carbon dioxide and incubation time. Thus, it's possible that some microorganisms which are responsible for dacryocystitis were not isolated in current conditions. Third, sample collection is a complex process which can easily be contaminated, even though we improved the sample collection method and verified most of the isolated microorganism was pathogenic microorganism, but we could not exclude the possibility of contamination by colonized microorganisms.

\section{Conclusions}

In adult dacryocystitis, gram positive and negative isolates were numerically equal to each other, indicating that gram negative isolates became more common in dacryocystitis than before [26-30, 36-40]. And Streptococcus pneumonia was still the most common organism in adult group. In pediatric dacryocystitis, gram positive isolates were much more common than gram negative isolates. Streptococcus pneumonia was the leading pathogen for chronic dacryocystitis with NLDO, and Staphylococcus aureus was the leading pathogen for acute dacryocystitis, indicating that the more virulent organisms were more common in acute dacryocystitis than chronic dacryocystitis with NLDO.

\section{Abbreviations \\ NLDO: Nasolacrimal duct obstruction}

\section{Acknowledgements}

Not applicable.

\section{Authors' contributions}

$\mathrm{BL}, \mathrm{ML}$, and $\mathrm{XY}$ were responsible for study design; $\mathrm{BL}, \mathrm{XY}, \mathrm{WH}$ and $\mathrm{NX}$ were involved in data collection; ML and RL conducted data analysis; BL, WH and $\mathrm{RL}$ drafted and wrote the manuscript; $\mathrm{XY}$ and NX revised the manuscript; All authors have read and approved the manuscript.

\section{Funding}

Not applicable.

\section{Availability of data and materials}

The datasets used and analysed during the current study available from the corresponding author on reasonable request.

\section{Ethics approval and consent to participate}

This study was approved by the ethics committee of Tongji Hospital and performed in accordance with the tenets of the Declaration of Helsinki. Written informed consents were obtained from all participants.

\section{Consent for publication}

Not applicable.

\section{Competing interests}

The authors declare that they have no competing interests.

\section{Author details}

'Department of Ophthalmology, Tongji Hospital, Tongji Medical College, Huazhong University of Science and Technology, 430030 Wuhan, China. ${ }^{2}$ Department of Ophthalmology, Union Hospital, Tongji Medical College, Huazhong University of Science and Technology, 430022 Wuhan, China. 
Received: 21 June 2020 Accepted: 26 December 2020

Published online: 11 January 2021

\section{References}

1. Marthin JK, Lindegaard J, Prause JU, Heegaard S. Lesions of the lacrimal drainage system: a clinicopathological study of 643 biopsy specimens of the lacrimal drainage system in Denmark 1910-1999. Acta Ophthalmol Scand. 2005;83(1):94-9.

2. Ramesh S, Ramakrishnan R, Bharathi MJ, Amuthan M, Viswanathan S Prevalence of bacterial pathogens causing ocular infections in South India. Indian J Pathol Microbiol. 2010;53(2):281-6.

3. Sihota R, Tandon R. Parson's Diseases of the Eye. 19th ed. New Delhi: Harcourt (India) Private Limited. 2003: 473-522.

4. Mitra S, Chayani N, Mohapatra D, Barik MR, Sharma S, Basu S. High Prevalence of Biofilm-Forming MRSA in the Conjunctival Flora in Chronic Dacryocystitis. Semin Ophthalmol. 2019;34(2):74-9.

5. Getahun E, Gelaw B, Assefa A, Assefa Y, Amsalu A. Bacterial pathogens associated with external ocular infections alongside eminent proportion of multidrug resistant isolates at the University of Gondar Hospital, northwest Ethiopia. BMC Ophthalmol. 2017;17(1):151.

6. Pollard ZF. Treatment of acute dacryocystitis in neonates. J Pediatr Ophthalmol Strabismus. 1991;28(6):341-3.

7. Mauriello JA Jr, Wasserman BA. Acute dacryocystitis: an unusual cause of life-threatening orbital intraconal abscess with frozen globe. Ophthalmic Plast Reconstr Surg. 1996;12(4):294-5.

8. Subbaiah S. Role of endoscopic dacryocystorhinostomy in treating acquired lacrimal fistulae. J Laryngol Otol. 2003;117(10):793-5.

9. Dirckx JH. Stedman's Concise Medical Dictionary for the Health Professions. 3rded. Baltimore: Lippincott, Williams \& Wilkins; 1997. p. 330.

10. Tasman W, Jaeger EA. Duane's Ophthalmology. Vol. 4. Baltimore: Lippincott, Williams \& Wilkins; 2006. p. 22.

11. Keilani C, Keller P, Piaton JM. Incision of Hasner's valve under endoscopic intranasal surgery for the treatment of nasolacrimal duct obstruction in children. J Laryngol Otol. 2020;134(1):56-62.

12. Liu R, Li H, Ai T, Hu W, Luo B, Xiang N. Pathological changes of the nasolacrimal duct in rabbit models of chronic dacryocystitis: correlation with lacrimal endoscopic findings. Graefes Arch Clin Exp Ophthalmol. 2018;256(11):2103-12.

13. Brook I, Frazier EH. Aerobic and anaerobic microbiology of dacryocystitis. Am J Ophthalmol. 1998;125(4):552-4.

14. Eshraghi B, Abdi P, Akbari M, Fard MA. Microbiologic spectrum of acute and chronic dacryocystitis. Int J Ophthalmol. 2014;7(5):864-7.

15. Mills DM, Bodman MG, Meyer DR, Morton AD 3rd, ASOPRS Dacryocystitis Study Group. The microbiologic spectrum of dacryocystitis: a national study of acute versus chronic infection. Ophthalmic Plast Reconstr Surg. 2007; 23(4):302-6.

16. Chung SY, Rafailov L, Turbin RE, Langer PD. The microbiologic profile of dacryocystitis. Orbit. 2019;38(1):72-8.

17. Briscoe D, Rubowitz A, Assia El. Changing bacterial isolates and antibiotic sensitivities of purulent dacryocystitis. Orbit. 2005;24(2):95-8.

18. Cahill KV, Burns JA. Management of acute dacryocystitis in adults. Ophthalmic Plast Reconstr Surg. 1993;9(1):38-41. discussion 42.

19. Yan X, Xiang N, Hu W, Liu R, Luo B. Characteristics of lacrimal passage diseases by $80-\mathrm{MHz}$ ultrasound biomicroscopy: an observational study. Graefes Arch Clin Exp Ophthalmol. 2020;258(2):403-10.

20. Mandal R, Banerjee AR, Biswas MC, Mondal A, Kundu PK, Sasmal NK. Clinicobacteriological study of chronic dacryocystitis in adults. J Indian Med Assoc. 2008;106(5):296-8.

21. Martins MC, Ricardo JR, Akaishi PM, Velasco e Cruz AA. Orbital abscess secondary to acute dacryocystitis: case report. Arq Bras Oftalmol. 2008;71(4):576-8.

22. Boynton JR, Drucker DN. Distention of the lacrimal sac in neonates. Ophthalmic Surg. 1989;20(2):103-7.

23. Campolattaro BN, Lueder GT, Tychsen L. Spectrum of pediatric dacryocystitis: medical and surgical management of 54 cases. J Pediatr Ophthalmol Strabismus. 1997; 34(3): 143 - 53; quiz 186-7.

24. Paysse EA, Coats DK, Bernstein JM, Go C, de Jong AL. Management and complications of congenital dacryocele with concurrent intranasal mucocele. J AAPOS. 2000:4(1):46-53.

25. Bharathi MJ, Ramakrishnan R, Maneksha V, Shivakumar C, Nithya V, Mittal S. Comparative bacteriology of acute and chronic dacryocystitis. Eye (Lond). 2008;22(7):953-60
26. Chaudhry IA, Shamsi FA, Al-Rashed W. Bacteriology of chronic dacryocystitis in a tertiary eye care center. Ophthalmic Plast Reconstr Surg. 2005;21(3): 207-10.

27. Coden DJ, Hornblass A, Haas BD. Clinical bacteriology of dacryocystitis in adults. Ophthalmic Plast Reconstr Surg. 1993;9(2):125-31.

28. DeAngelis D, Hurwitz J, Mazzulli T. The role of bacteriologic infection in the etiology of nasolacrimal duct obstruction. Can J Ophthalmol. 2001;36(3): 134-9.

29. Assefa $Y$, Moges F, Endris M, Zereay B, Amare B, Bekele D, et al. Bacteriological profile and drug susceptibility patterns in dacryocystitis patients attending Gondar University Teaching Hospital, Northwest Ethiopia. BMC Ophthalmol. 2015;15:34

30. Amin RM, Hussein FA, Idriss HF, Hanafy NF. Abdallah DM. Pathological, immunohistochemical and microbiologicalal analysis of lacrimal sac biopsies in patients with chronic dacrocystitis. Int J Ophthalmol. 2013:6(6):817-26.

31. Teweldemedhin M, Gebreyesus H, Atsbaha AH, Asgedom SW, Saravanan M. Bacterial profile of ocular infections: a systematic review. BMC Ophthalmol. 2017;17(1):212.

32. Kebede A, Adamu Y, Bejiga A. Bacteriological study of dacryocystitis among patients attending in Menelik II Hospital, Addis Ababa, Ethiopia. Ethiop Med J. 2010;48(1):29-33.

33. Bekmez S, Eris E, Altan EV, Dursun V. The Role of Bacterial Etiology in the Tear Duct Infections Secondary to Congenital Nasolacrimal Duct Obstructions. J Craniofac Surg. 2019;30(7):2214-6.

34. Ali MJ, Motukupally SR, Joshi SD, Naik MN. The microbiological profile of lacrimal abscess: two decades of experience from a tertiary eye care center. J Ophthalmic Inflamm Infect. 2013;3(1):57.

35. Thiel HJ, Schumacher U. Ueber die Standortflora der menschlichen Bindehaut: Untersuchungen von 135 Personen unterschiedlichen Alters. Klin Monatsbl Augenheilkd. 1994;205(6):348-57.

36. Hartikainen J, Lehtonen OP, Saari KM. Bacteriology of lacrimal duct obstruction in adults. Br J Ophthalmol. 1997;81(1):37-40.

37. Huber-Spitzy V, Steinkogler FJ, Huber E, Arocker-Mettinger E, Schiffbänker M Acquired dacryocystitis: microbiology and conservative therapy. Acta Ophthalmol (Copenh). 1992;70(6):745-9.

38. Pornpanich K, Luemsamran P, Leelaporn A, et al. Microbiology of primary acquired nasolacrimal duct obstruction: simple epiphora, acute dacryocystitis, and chronic dacryocystitis. Clin Ophthalmol. 2016;10:337-42.

39. Razavi ME, Ansari-Astaneh MR, Farzadnia M, Rahmaniyan H, Moghiman T. Bacteriological evaluation of adult dacryocystitis in Iran. Orbit. 2010;29(5):286-90.

40. Shiferaw B, Gelaw B, Assefa A, Assefa Y, Addis Z. Bacterial isolates and their antimicrobial susceptibility pattern among patients with external ocular infections at Borumeda hospital, Northeast Ethiopia. BMC Ophthalmol. 2015;15:103.

\section{Publisher's Note}

Springer Nature remains neutral with regard to jurisdictional claims in published maps and institutional affiliations.

Ready to submit your research? Choose BMC and benefit from:

- fast, convenient online submission

- thorough peer review by experienced researchers in your field

- rapid publication on acceptance

- support for research data, including large and complex data types

- gold Open Access which fosters wider collaboration and increased citations

- maximum visibility for your research: over $100 \mathrm{M}$ website views per year

At $\mathrm{BMC}$, research is always in progress.

Learn more biomedcentral.com/submissions 